\title{
English Proficiency of Secondary School Teachers in Indonesia
}

\author{
Anita Lie \\ anita@ukwms.ac.id \\ Siti Mina Tamah \\ mina@ukwms.ac.id \\ Trianawaty \\ trianawaty@ukwms.ac.id \\ Universitas Katolik Widya Mandala \\ Surabaya, Indonesia \\ Katarina Retno Triwidayati \\ retno@ukmc.ac.id \\ Universitas Katolik Musi Charitas \\ Palembang, Indonesia \\ Fransiskus Jemadi \\ ikinjemadi@gmail.com \\ STKIP Santu Paulus \\ Ruteng, Indonesia
}

\begin{abstract}
Responding to the growing need to foster communicative abilities in English, schools in Indonesia are driven to make their students proficient in English. However, the majority of English teachers themselves are still not prepared to use English as a means of communication; improving their English proficiency has thus become a matter of concern. As the first phase of a larger-scale study, this present study focuses on teachers' English proficiency. Data for this study were collected from 149 secondary school teachers of English from five regions (Palembang, Yogyakarta-Sleman, Surabaya, Ruteng, and Maluku). They were asked to self-assess their English proficiencies based on the ACTFL (American Council on the Teaching of Foreign Languages) guidelines as well as to do an English Proficiency assessment. Fifty-two of these participants were teachers who were completing an in-service professional education program in Surabaya. The teachers assessed their proficiencies in interpersonal communication, presentational speaking, presentational writing, interpretive listening, and interpretive reading. The English Proficiency assessment includes syllabus-oriented items, General English items, and an essay. The study also conducted in-depth interviews of selected teachers. This study found that there is a gap between the teachers' perception of their communicative abilities in English and their actual English proficiency.
\end{abstract}

Keywords: English proficiency, teachers, Indonesia, professional development

\section{Introduction}

In many countries including Indonesia, the quality of its education. All teachers the teaching profession is still characterized must meet the minimum standards of a fourby its low quality and levels of competence. year degree and should be formally certiThe Indonesian government realises that teacher quality is a prerequisite to improve fied. They have to attend in-service teacher professional development programmes and 
take a series of teacher assessment to earn teaching certificates. On a different note, a study on teachers in remote areas finds that when government-initiated professional development programme is non-existent, community-based professional development sessions have enabled teachers to enhance their knowledge of pedagogical content (Harjanto, Lie, Wihardini, Pryor, \& Wilson, 2018).

Despite the ambitious plan to upgrade teacher quality and the progresses in some areas, in many school systems, teachers find it extremely hard to participate in continuing professional development (CPD). They have long hours of teaching (in many cases, more than 28 periods of teaching in a week), demanding administrative work, committee tasks, and various extra-curricular activities. Teachers of English are compelled to improve their English proficiency and enhance their professional development. In 2018, the Ministry of Education and Culture, in collaboration with the Ministry of Research and Higher Education, set up an in-service professional education program system as a path toward teacher certification (Pendidikan Profesi Guru Dalam Jabatan, hereinafter referred to as In-Service TPE). The program involves a hybrid learning management platform of 12 modules of online classes, 256 hours of on-campus workshops including classroom teaching and action research proposal development. Each batch consists of 30 in-service teachers facilitated by professors and lecturers of a participating teacher college.

This paper reported a study investigating the perception of communicative abilities in English among in-service English teachers and their tested English Proficiency. Specifically, this study intends to answer the following research questions:

1. How do in-service English teachers perform in a proficiency test?

a. How do novice English teachers perform in a proficiency test?

b. How do mid-career (apprentice and practitioner) English teachers perform in a proficiency test?

c. How do senior English teachers perform in a proficiency test? To what extent do in-service English teachers' perceptions of their English communication ability in the five proficiency areas (interpersonal communication, presentational speaking, presentational writing, interpretive listening, and interpretive reading) correlate with their tested English proficiency?

2. How do teachers maintain, lose, or improve their English proficiency as they go through their professional journey?

\section{Lite rature Review}

This research stems from the necessity of awareness for teachers as lifelong learners and reflective pedagogical thinkers (Grossman, 1992). Mehrpour and Moghadam (2018) compared novice and experienced Iranian EFL teachers and found that novice teachers became more competent and grew into a state of maturity as they converged their belief and practices. Teach- er professionalism can be viewed from the development perspectives. A few studies propose teacher professional development stages. The staging of professional development is used to help identify teachers' learning needs, enhancement process and the requirement for professional learning cycles during their professional journey. Hargreaves (2000) described teacher profes- 
sionalism based on the teacher response to the demands of the profession over different time periods. Hargreaves (2000) noted four ages of teacher professionalism: the age of pre-professionalism (when teachers are more concerned with the overall delivery of the lesson than the learning experiences of individual students); the age of autonomous professional (when teachers become more knowledgeable and skilled but remain isolated); the age of collegial professional (when teachers collaborate in the organization to enhance the quality of classroom instruction), and the age of postprofessionalism (when teachers engage with the parents and wider community in responding to external demands). Within this context, teacher professionalism should be viewed as a continuously developing journey to fulfill the needs of the schools and students.

While Hargreaves presented the four ages of teacher professionalism as seen in the state of the profession in several countries, Robyn Jackson (2009) identified the four stages as novice, apprentice, practitioner, and master. Referring to Hargreaves and Fulan's framework (2012), Yumarnamto (2017) studied critical events in an EFL teacher's life and revealed that professional capital involving the human, social, and decisional capital enhance professionalism and that decisions at the micro and macro levels shape a teacher's professional journey.

With the increasing importance of English as a language of global communication, teachers of English, particularly, are compelled to demonstrate their English proficiency. To serve as a model of acceptable language speakers for their students, teachers need to demonstrate in-depth and adaptable knowledge of the field, which could be enhanced through professional development (Borko, 2004). Schools have invested in more hours of English instruction and need more qualified English teachers. Therefore, the teachers' English proficiency has drawn research interest particularly in countries where English is not the lingua franca.

The competence of teachers of English has been the focus of a number of studies. In her investigation of 20 primary school English teachers in Hong Kong, Tsang (2011) examined to what extent her subjects were aware of English metalanguage and found the need for regular or systematic use of metalanguage among school teachers. Othman and Nordin (2013) studied the correlation between the Malaysian University English Test (MUET) and academic performance of English pre-service teachers while Sharif (2013) suspected that teachers' limited English proficiency hindered students' understanding of the content. More recently, Nair and Arshad (2018) analyzed the discursive construction of Malaysian English language teachers in connection with the Malaysian Education Blueprint action plan from 2013 to 2015 and recommended ways to help teachers achieve the desired proficiency and make changes to existing classroom practices that were aligned with the government agenda. In her study of twelve English teachers in Hong Kong, Tsang (2017) concluded that it was important for English teachers to reach a threshold of English proficiency but other factors such as pedagogical practices played a more significant role in overall teaching effectiveness. Richards (2017) confirms that a threshold level of proficiency is needed for teachers to be able to teach through English.

A number of studies on teachers' English proficiency in Indonesia have also been conducted. A study (Lengkanawati, 2005) investigating the English proficiency of teachers in West Java used a TOEFL- 
equivalent test and revealed that the majority of the teachers did not show a satisfactory proficiency level. Lie (2007) urged that to set advanced competencies in the English curriculum, Indonesian teachers' English proficiency first had to be improved. Aniroh (2009) discussed the need for ESP teachers to have a set of qualities, one of which is proficiency in English but she did not further elaborate on the proficiency issue. In their qualitative study of professional competence of English teachers in Indonesia, Anugerahwati and Saukah (2010) compiled a profile of exemplary teachers based on qualitative descriptions of their four research subjects. They claimed that satisfactory competence in English may have been taken for granted by many people other than the English teachers themselves. The guarantee of subject matter competence through the teachers' formal education is still very much debatable as graduate competence standards are still yet to be established and enforced in English teacher education.

Assessing English teachers' competence remains an important issue. Soepriyatna (2012) assessed competence of high school teachers of English in Indonesia and set three dimensions of English language competence domain (language skills, linguistic, and sociocultural), two dimensions of content knowledge domain, and seven dimensions of teaching skills domain. The language proficiency covered in the first two domains was addressed in performance indicators statements such as "uses vocabulary correctly and appropriately" and "maintains grammatical accuracy." Soepriyatna did not, however, address how those indicators could be determined reliably.

A test specifically constructed to assess the English proficiency of high school teachers is yet to be developed in Indonesia.
The Ministry of Education and Culture had been administering annual Teacher Competency Test for all teachers as part of the certification process until it was replaced by the In-Service TPE. The online test comprises subject area and pedagogy items. Therefore, it does not specifically address language proficiency. Furthermore, there have been concerns that the test was not adequately constructed (Prasetyo, 2017; Putra, 2017). Coleman (2009) reported that a survey of 27,000 teachers in International Stand ard junior secondary, senior secondary and vocational secondary schools by the Ministry of Education revealed that more than half of all teachers and headteachers possess only a 'novice' proficiency level in English, scoring between 10 and 250 on a 990 point scale. The construct of this test is not accessible and this test has not been administered to all English teachers in the regular schools. A number of universities have developed English proficiency tests to assess their own students but official data on English teachers' proficiency at the national level are not available for scholarly discussion.

As Renandya, Hamid, and Nurkamto (2018) urge, "there is a pressing need to establish a national framework of English language proficiency so that appropriate standards can be established for students and teachers at all educational levels" (p. 625) because English language proficiency is a significant part of an English teacher's professional competence. Tamah \& Lie (2019) developed an English proficiency test comprising 16 general English, syllabusoriented multiple choice items (31 for junior high school and 36 for senior high school level), and an essay prompt instructing teachers to write a three-paragraph reflection of their professional journey and aspiration. The article discusses the construct of 
the English Proficiency assessment while this present study puts forward the results of that assessment administered to in-service English teachers at different stages of their professional development in relation to their perception of communicative abilities in English.

\section{Method}

Through survey, proficiency assessment, reflective essay, and interviews, this research derives teachers' perceived communicative abilities in English, their tested English proficiency, and their efforts to enhance their professional growth. Perception survey and proficiency assessment were administered. Select participants were later called for an in-depth interview.

\section{Contexts and Participants}

The participants of the study were 149 teachers of English from various state and private secondary schools in five regions (Palembang, Yogyakarta-Sleman, Surabaya, Ruteng, and Maluku). Fifty-two of the participants were teachers from various state and private secondary schools in East Java participating in an In-Service TPE in 2018 toward their certification. They belonged to two batches of the program delivered at the Faculty of Teacher Training and Education of a private university in Surabaya. Eight out of 30 teachers from the first batch declined to participate in this study. Participants of the program applied through their SIM PKB (Sistem Informasi Manajemen Pengembangan Keprofesian Berkelanjutan trans., Management Information System of Continuous Professional Development) online account and did a pre-test. They were selected based on their pre-test score and years of service. The pre-test consisted of four aspects of competence: professional competence, pedagogical competence, psychological competence, and aptitude. Other than the test results, priority must be given to those teachers who were still young and on high demand in their area.

Participants were categorized by the number of years of their teaching experience and the following table shows the composition:

Table 1

Number of Participants by the Number of Years of Their Teaching Experience

\begin{tabular}{l|c|c|c|c|c|c}
\hline $\begin{array}{l}\text { Venue of } \\
\text { Assessment }\end{array}$ & $\begin{array}{c}\text { less than } \\
5 \text { years }\end{array}$ & $\begin{array}{c}5-10 \\
\text { years }\end{array}$ & $\begin{array}{c}10-15 \\
\text { years }\end{array}$ & $\begin{array}{c}\text { more than } \\
15 \text { years }\end{array}$ & unknown & Total \\
\hline Palembang & 4 & 5 & 4 & 15 & 2 & 30 \\
\hline $\begin{array}{l}\text { Yogyakarta } \\
\text {-Sleman }\end{array}$ & 1 & 3 & 2 & 23 & & 29 \\
\hline Surabaya & 5 & 45 & 2 & - & - & 52 \\
\hline Ruteng & 7 & 8 & - & 5 & 1 & 21 \\
\hline $\begin{array}{l}\text { Ambon- } \\
\text { Saumlaki } \\
\text { (Maluku) }\end{array}$ & 3 & 3 & 8 & 3 & - & 17 \\
\hline Total & 20 & 64 & 16 & 46 & 3 & 149 \\
\hline
\end{tabular}

This study did not use a random sampling of the teacher population in each area because the researchers were not entitled to secure teachers' willingness to take part in the study voluntarily. Therefore, the researchers collaborated with local teacher councils (Musyawarah Guru Mata Pelajaran or MGMP) which issued an an- 
nouncement to all their members for a seminar and data collection. Invitations in each region were limited to a maximum of 30 participants on a first-response-first-served basis. The seminar and data collection were held in a member secondary school in each region except for the In-Service TPE groups in Surabaya. In light of the nature of the participants' selection, the makeup of the teacher participants in Table 1 does not represent the actual teacher force in the five regions. The participants in this study were simply those teachers who responded to the invitations and thus were somewhat interested in their professional development.

It should be noted that the participants from the assessment-survey administered in Surabaya are teachers from various towns in East Java who were taking part in the InService TPE at Widya Mandala Catholic University in Surabaya. The majority of these teachers were between 5-10 years in their career stage as teachers. This fact is due to the policy by the education authority to recruit teachers who have served more than five years and are still young enough to work their way through their professional journey. Almost all the teacher participants graduated from teacher colleges. Only one or two teachers in each region graduated from non-education majors.

\section{Data Collection}

To collect the data, the researchers first developed instruments including the English proficiency test, survey, and protocol for the semi-structured interview. The English proficiency assessment consisted of syllabusoriented items, General English items, and a prompt for a reflective essay.

The assessment was pilot-tested among pre-service English teachers and final-semester students majoring in English Education in Surabaya and in Ruteng, East Nusa Tenggara. The pilot test in Surabaya was administered via Google Form while the one in Ruteng was paper-based due to poor internet connection in that area.

Three test types were utilized: Multiple Choice, Cloze test, and Writing. Sixtyfive items were initially developed (50 Multiple Choice items and 15 Cloze test items). The objective test type included grammar and reading comprehension (a test specification was prepared for test validity issue). With regard to $\mathrm{P}$ value and $\mathrm{D}$ value among the $50 \mathrm{MC}$ items, it was found that $26 \%$ items belong to easy category (ranging from .75 to 1$), 64 \%$ items belong to average category (ranging from .32 to .7), and $10 \%$ items belong to difficult category (ranging from .07 to .29). More detailed information about the test analysis was separately described in another article (Tamah \& Lie, 2019). With regard to the Cloze test set, it was found that $15 \%$ items were easy (ranging from .79 to .89), $75 \%$ average (ranging from .68 to .32 ), $10 \%$ difficult. The devised test reached the category of ave rage level of item difficulty and the classification of good at discriminating between the high and low achieving test takers.

The total number of items became 52 (scored for 100 for all correctly answered items). The writing test was devised for the teachers to write a three-paragraph essay about their teaching career (why they become a teacher and what their plan for their professional development). The essay assessment rubric included the evaluation to these five components: main idea, organization (overall), content, style (details and examples), and grammar and mechanics. The score ranged 0-100. Two raters were involved in blind review, but only one rater was involved in the other objective test types.

Based on the pilot test results, an item analysis was conducted and the assessment 
was revised accordingly. The junior high school assessment instrument was found to have a reliability of 0.698 while the senior high school assessment 0.818. The development process of this assessment was separately described in another article (Tamah \& Lie, 2019).

As triangulation, participants wrote reflective essays describing their professional journey. Each of the participants' reflective essays was read and assessed by two reviewers based on a given rubric. All the essays were blind-reviewed. An inter-rater reliability was established at a Pearson $r$ of 0.84 .

Through a survey built upon the ACTFL Can-Do Statements, this research derives teachers' perceived communicative abilities in English in the five proficiency areas (interpersonal communication, presentational speaking, presentational writing, interpretive listening, and interpretive reading). In collaboration with the National Council of State Supervisors for Languages (NCSSFL), American Council on the Teaching of Foreign Languages (ACTFL) developed the Can-Do Statements to provide proficiency benchmarks and performance indicators. The statements are specified into five proficiency areas (interpretive listening and interpretive reading, interpersonal communication, presentational speaking, and presentational writing). The statements reflect the continuum of growth in communication skills through the Novice, Intermediate, Advanced, Superior, and Distinguished levels (https://www.actfl.org/ publications/guidelines-and-manuals/ncssflactfl-can-do-statements).

For each of the five proficiency areas, there are eleven Can-Do Statements which denote a range of abilities from Novice Low to Distinguished as follows: 1) Novice Low, 2) Novice Mid, 3) Novice High, 4) Interme- diate Low, 5) Intermediate Mid, 6) Intermediate High, 7) Advanced Low, 8) Advanced Mid, 9) Advanced High, 10) Superior, and 11) Distinguished

A protocol for the semi-structured interview was developed to elicit insights from a select number of participants. Each interview was conducted by two researchers for a period of 30 minutes. The interview was administered on campus. It was recorded and then transcribed.

Prior to participation in the research, all participants were given information about the purpose and procedures of the research; they were also told that their participation was voluntary. For 52 teachers participating in the In-Service TPE in 2018, the administration of the research was conducted by a research assistant who was not involved in the program to avoid conflict of interest and thus the research participants were aware that their participation had no effect on their success or failure in the professional education program.

\section{Data Analysis}

The data collected from the assessment, survey, and semi-structured interview were analyzed quantitatively and qualitatively. The quantitative analysis was conducted through descriptive statistics while the qualitative analysis was based on the content of the essays and interviews.

To answer Research Question 1, the study did a Mean, Range, and Standard Deviation calculation for the different groups of teachers. A correlation computation was afterwards done on the ACTFL Scores and the English Proficiency Assessment Scores to answer Research Question 2. The correlations were obtained for the overall group, different groups by location of assessment, and by stages of professional development.

The interviews were conducted in both English and Indonesian. The written notes 
of interviews were transcribed, categorized and compiled together into themes. The Indonesian parts of the interviews were translated into English. Analysis and interpretations were made on the basis of the assessment scores, survey results, and reflective essay analysis. Ultimately, the teachers' re- flective essays and interview transcripts were coded into related themes to reveal patterns for further interpretation (Miles, Huberman, \& Saldana, 2014). The insights gained through the essays and interviews were collected to answer Research Question 3.

\section{Findings and Discussion}

In light of the references of the teacher professional development stages (Hargreaves, 2000; Jackson, 2009), secondary school teachers of English in this study were categorized into four stages based on the number of years of their teaching experience:

1. Novice (less than 5 years)

2. Apprentice (between 5-10 years)

3. Practitioner (between 10-15 years)

4. Senior (more than 15 years)

The novice teachers feel inadequate and unprepared in terms of their English language proficiency as well as their pedagogical practices but they usually demonstrate initial enthusiasm for development. They focus on curriculum coverage and task completion. The perceived lack of English language proficiency may impede the use of English as a medium of instruction, even in the English language classroom. The apprentice teachers begin to feel more confident of their English language proficiency although some of them may still not be able to engage their students in English as a medium of instruction fluently. They also choose which activities and assessment they use to meet their students' interests. The practitioners make conscious choices about their professional practices based on experience. They align assessments and learning activities to learning goals. At the senior level, teachers reach stability and feel more confident about their pedagogical practices but may experience a decline in ambition for their professional development.

\section{English Proficiency among Different Teacher Groups}

The results of the English proficiency assessment revealed different levels among teachers across the regions as well as their stages of professional development. The following table shows a summary of means of the assessments grouped by the location of assessment:

Graph 1

Mean of English Proficiency Assessment by Location of Assessment

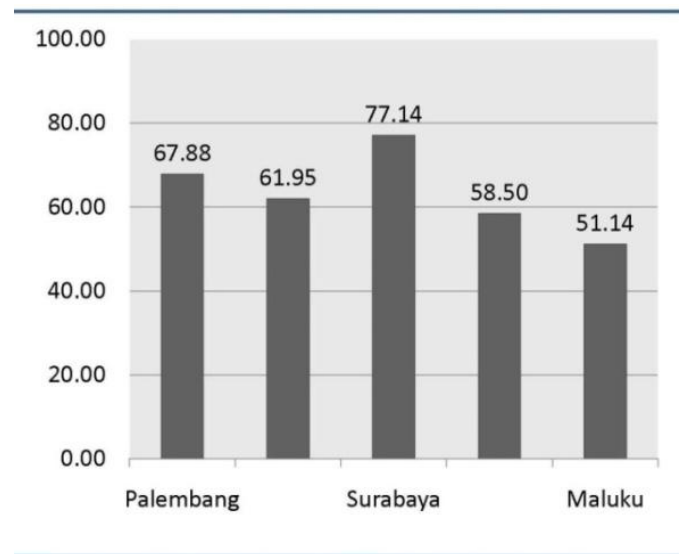

As seen in Graph 1, teacher participants who did their assessment and survey in Surabaya gained the highest mean (Mean: 77.14, SD: 10.73) while participants in Palembang (Mean: 67.88, SD: 10.77) and Yogyakarta (Mean: 61.95, SD: 9.23) scored the second and third places respectively. The two lowest average scores belonged to teacher participants from Ruteng (Mean: 58.50, SD: 14.25) and Maluku (Mean: 51.14, SD: 22.35) respectively.

Although the study participants were not selected by random sampling, the results were fairly in line with other indicators of development across regions such as human 
development index (in 2017, South Sumatera: 68.86, Yogyakarta: 78.89, East Java: 70.27, East Nusa Tenggara: 63.73, Maluku 68.19).

The result indicating the mean for the Surabaya group is the highest may be explained by the nature of the group - a special group of In-Service TPE participants. They had been selected through an online selection system administering a pre-test and local education authorities. They were deemed to deserve a chance for teacher certification. Furthermore, this group age may also be a determining factor which is revealed in the following summary of the mean of the English proficiency assessment by their stages of professional development and the locations of assessment:

Graph 2 shows that the four stages of professional development (novice, apprentice, practitioner, and senior) are represented in the Palembang, Yogyakarta, and Maluku). The teachers doing the assessment in Surabaya were younger; none of them had been teaching more than 15 years. The Ruteng group did not by chance have the practitioner teacher as samples. Other than comparing the means, it is also interesting to note that the two lowest regions (Ruteng and Maluku) show higher standard deviations-14.25 and 22.35 respectively. The Range of scores in Maluku is very large (54.84). The highest score earned by a practitioner (10-15 years of experience) teacher was 82.69 while the lowest 28.85 was scored by a senior teacher. A similar situation (Range 64.47) was found in Ruteng. The highest score-by an apprentice teacher of 5-10 years-was 78.85 while the lowest 15.38 was also scored by a senior teacher. Viewed in a positive way, this finding may indicate hope for a more progressive teacher force for those two regions.

Graph 2
Mean of English Proficiency Assessment by Stages of Professional Development and Locations of Assessment

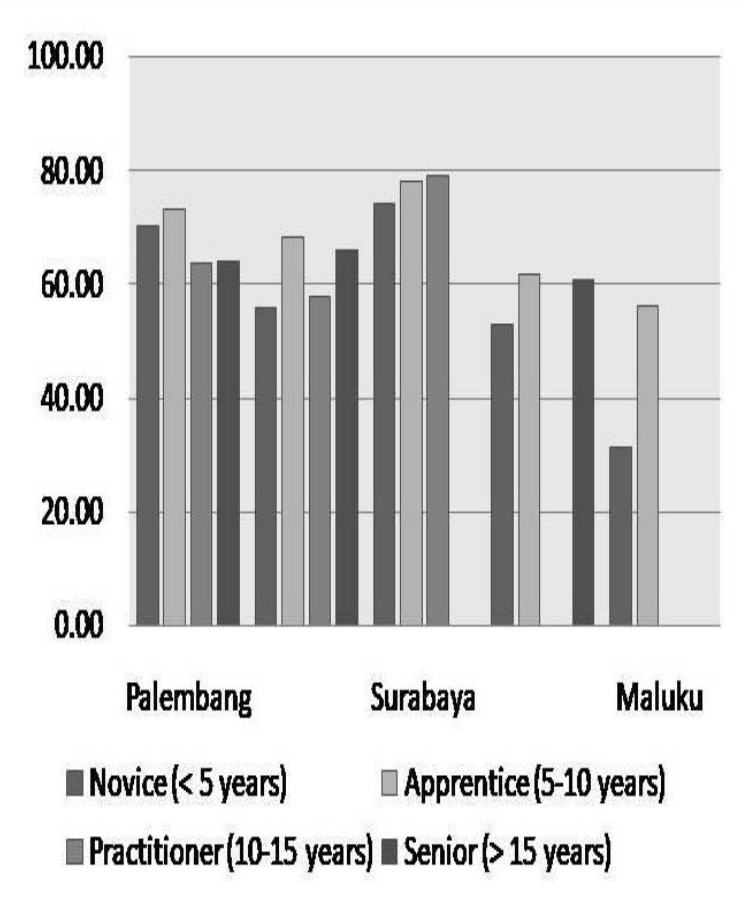

In regard of progress among teachers of English, a summary of the means grouped by the stages of development shows the different proficiency levels as teachers went through their professional journey as seen in the following graph:

\section{Graph 3}

Mean of English Proficiency Assessment by Stages of Professional Development

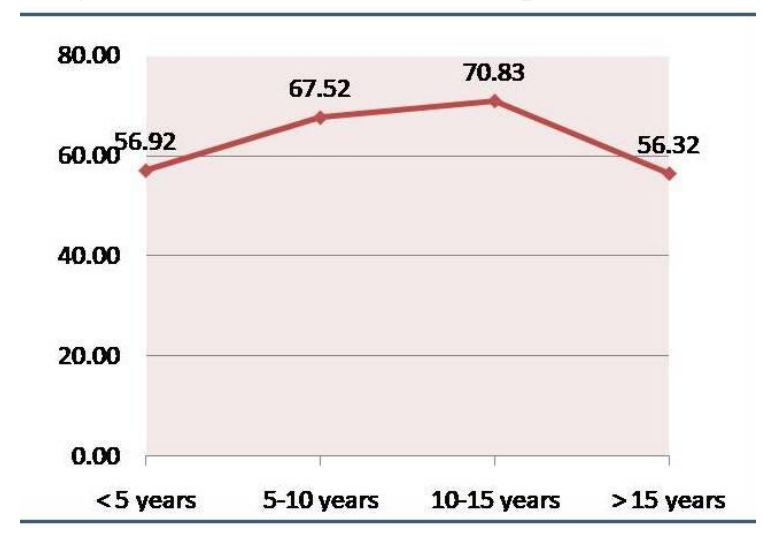

Overall, the practitioner group of teachers scored the highest while the senior 
teacher the lowest. The findings are in line with the identification of the stages of professional development that notes the development of confidence and familiarity with the field during the third stage and the decline in ambition for professional development among senior teachers (Hargreaves, 2000; Jackson, 2009). The low mean in the novice group of teachers is certainly a serious concern. This finding matches with the survey of 27,000 teachers International Standard schools by the Ministry of Education showing poor proficiency level (Coleman, 2009). This issue requires serious commitment to upgrade teachers' English proficiency as well as the quality of English teacher colleges.

\section{Teachers' Perceptions}

Teachers' perceptions of their communicative abilities in English varied across regions and stages of professional development. The full spectrum (from 1. Novice Low through 11. Distinguished) of communication abilities was chosen by different teachers. Overall, teachers' perceptions of their English ability as reflected in the ACTFL survey do not match with their tested English proficiency. An analysis of all the ACTFL scores and the assessment scores yielded a correlation of 0.199 . This means that some teachers overestimated their English ability. For instance, one teacher who thought of herself as superior in one of the proficiency areas scored only 43.75 in the proficiency test. On the other hand, a few teachers who scored rather high on the test did not attribute a high estimate of their ability. Eighteen of 149 participants thought of themselves as either superior or distinguished in some of the proficiency areas while only one of them scored above 90 in the proficiency as sessment, two others scored 84 and 87 , and the rest ranged from 21 to 78 . Those who scored very low on the proficiency test but chose high marks on the ACTFL may just have mostly misunderstood the Can-Do statements. This is definitely a serious issue in regard of the quality of English instruction in secondary schools in Indonesia. Improvement of teachers' English proficiency is undoubtedly a pressing need. While the Ministry of Research and Higher Education, along with the Ministry of Education and Culture, are currently administering the InService TPE, a higher standard of English proficiency has to be set up in the selection process as a pre-requisite for participation in the program.

Table 2

Correlation of Perceptions and Proficiency Test Results by Stages of Development

\begin{tabular}{lcc}
\hline Stage & In & Correlation \\
\hline Novice & 20 & 0.27 \\
\hline Aprentice & 64 & 0.11 \\
\hline Practitioner & 16 & 0.73 \\
\hline Senior & 46 & 0.19 \\
\hline Unknown & 3 & \\
\hline & 149 & \\
\hline
\end{tabular}

The correlation between perceptions of teachers' English abilities and the tested proficiency is very low in the whole group. However, when the different groups were considered, there is a variation of correlations. The Maluku group yielded a correlation of 0.748 between the teachers' perceptions and their tested proficiency scores while the Surabaya group registered the lowest correlation coefficient of 0.169 .

The variation also occurs across the different stage groups as seen in the table above.

The practitioner group reached the highest correlation between their perceptions of abilities and their tested proficiency scores. This group also scored the highest in the proficiency test as has been discussed in the pre- 
vious section. The mean of this group is70.83. Their language proficiency is adequate enough to conduct a proper selfreflection and meta-evaluation of their own communication abilities in English. Specifically, their language proficiency has also enabled them to do the assessment as well as comprehend the Can-Do Statements.

This study offers a caveat that the size of the practitioner group is small (n. 16) and thus the findings cannot be generalizable. The small size of this group is inevitable as the researchers had no control of who would take part in the study and from which stage group those participants were.

Implications on the Path of Maintaining, Losing, or Improving English Proficiency

Four teachers who obtained incongruent perception survey and test scores were selected for in-depth interviews. As a comparison, two teachers with correlated scores were also interviewed. During the interviews, teachers were not informed about their scores. Interview questions included how they felt about the survey and test, what they thought about their English proficiency, why they thought that way, and what they did to improve their English. Interviews were conducted in September and October 2018. This section presents three types of teachers in terms of their perception of their performance and their tested proficiency.

The first type of teachers underestimated their performance. As a novice teacher (less than five years of service), Teacher PS regarded her English communication abilities as Novice-Mid while she scored 78.85 in the proficiency test. An apprentice teacher SK chose Intermediate-Mid while she scored 73.08. When asked about the survey and test, they both said they were not confident about their English and so chose what they did. Teacher PS graduated from Madrasah Aliyah (an Islamic boarding school) in
Bojonegoro and Teacher SK from Madrasah Aliyah in Kediri. Thinking that their secondary school education was not adequate, they separately enrolled themselves in Kampung Inggris (an immersion boarding English course) in Pare Kediri. PS studied in the course for one month in 2010 before enrolling herself in IKIP (Teacher College) PGRI in Bojonegoro. SK had had a more winding journey. After her secondary school graduation, she did not think about college education. Instead, she learned English in Kampung Inggris for nine months in 2003. Then she taught English in her friend's English course in Madura. After she had got married, she decided to continue her study in college. At the time of interview, both PS and SK taught in Islamic boarding schools in Bojonegoro and Banyuwangi respectively. The interviews were also conducted in English. Both teachers tried hard to engage in conversations in English. They were fairly fluent but sometimes stumbled on some expressions. Yet, they were not able to use full English when teaching their students because the students would not understand it.

The second type overestimated their ability. Teacher S scored 61.53 in the proficiency test but thought of himself at the Advanced Mid level. When asked about the survey and test, he even said that he was not confident enough to mark himself well in the survey. He thought he assessed himself lower than his actual proficiency. Teacher $\mathrm{S}$ was not able to respond to interview questions in English. Regarding his English proficiency, he felt more capable when he was still a student. In college, he had good teachers that encouraged him to speak English. "Sekarang jadi guru, malah lebih goblok" (Now that I'm a teacher, I've become dumber). As an apprentice teacher, he felt he had lost quality chances to enhance his English. He did not have counterparts to use his English. Teacher 
S often skipped meetings by MGMP (the local teacher councils) because he thought they were just a waste of time. Another case in point, Teacher MW was an apprentice teacher in Ruteng. She marked herself as above superior but scored 53.84. Similar to Teacher S, MW did not have much chance to practice her English. She used Indonesian as the medium of instruction in her English class because her students would not understand it if she spoke English.

The last type is those who got congruent scores in their perception and tested proficiency. Two teachers were selected to represent this group. One is an apprentice (5-10 years of service) teacher who participated in the In-Service TPE in Surabaya and the other one a practitioner (10-15 years of service) teacher teaching in a private senior secondary school in Ambon, Maluku. Both of these teachers chose Advanced Mid in the ACTFL survey. In the proficiency assessment PW, the apprentice teacher, scored 78.83 while MM, the practitioner teacher scored 82.69. Interviews with both of them were conducted in English. They spoke English fluently; they were able to describe their professional journey and their experiences as English teachers. They also expressed themselves well in writing. PW's essay scored an average of 87.00 and MM's essay 93.79 by two graders.

When asked about doing the ACTFL and proficiency test, teacher PW said that she just felt right. Regarding her English proficiency, at the beginning of her teaching career, she felt her English was inadequate because she taught in one of the prestigious private junior secondary schools in Surabaya. Her students challenged her to improve her English. They read English novels in their spare time and often asked her about difficult vocabularies and expressions. Furthermore, there were times that she used Indonesian in class to adjust to her weaker students coming from less developed regions. Then her brighter students bluntly reminded her that it was an English class and thus she was supposed to be speaking English. So, Teacher PW pushed herself to enhance her English by reading, searching for references, and finally enrolling herself in a Master program. Teacher MM described herself as a confident person and so she did both the survey and test comfortably. She had started teaching English in a course before her undergraduate completion in 2003. Then she moved to Ambon and taught at a private senior secondary school in 2008. In 2014, she did her Masters while continuing to teach in her school. Furthermore, MM made conscious efforts to improve her English by attending seminars, participating in MGMP events, reading, corresponding with foreigners, and communicating with other English teachers in English. She found those activities useful not only to enhance her English but also "to enrich my knowledge of the world." Contrary to Teacher S, MM believed that the MGMP activities were important for her because members discussed the updated curriculum, syllabus, teaching methods and techniques, and relevant experiences.

\section{Conclusions and Recommendations}

Through the quantitative and qualitative analyses, four deductions are offered in relation to teachers' path in maintaining, losing, or improving their English proficiency throughout their stages of professional development. First, at the entry point, teachers do not start at the same level. Minimal standards of higher education have been set by the 
government but at the implementation level, teacher colleges have different levels of commitment to quality assurance. Therefore, teachers in our study demonstrate various levels of English proficiency from novice low to advanced high. Many teachers have not achieved the threshold level, as Tsang (2017), Richards (2017), and Renandya, Hamid, and Nurkamto (2018) propose.

Second, individual teachers also demonstrate different levels of commitment in regard of their own professional development. Aware of their limited English proficiency, the more committed teachers make conscious efforts to fill in the gap by taking part in seminars, reading English books, participating in MGMP activities, communicating in English, and taking a Master program. Unfortunately, some other teachers become apathetic and have plateaued out.

Third, in regard of Hargreaves' four ages of teacher professionalism (2000), because of remoteness issues in some regions in Indonesia, some teachers get stuck in the age of preprofessionalism. They are more concerned with the overall delivery of the lesson than the learning experiences of individual students or their own professional development.

Finally, the first deduction is extended when teachers end up in schools of different levels of quality commitment. Those in better schools are continuously challenged to improve their proficiency and pedago gical practices while others in underprivileged schools have no agency to remind them of their lacking. English teachers need professional communities to grow. To move from the age of autonomous professional, teachers need others (students, fellow teachers, university teachers, and the wider community) to see the external demands and challenge them to enhance their professional development.

Based on the insights gained through this study, we offer three recommendations:
1. 2018 is a significant milestone when the Ministry of Research and Higher Education and the Ministry of Education and Culture set up the certification system through the hybrid learning management. This InService TPE has been an improvement of the previous systems but this needs to be further improved. One point to upgrade is the passing score of the English proficiency selection test. Should a higher passing score not be feasible for most teachers in Indonesia, an online English tutorial should be provided for teachers to reach the threshold level.

2. Certification should not be the end of a teacher's professional journey. As our study reveals that senior teachers show lower proficiency scores, English teachers must take language proficiency and pedagogical competence assessments periodically to ensure they move up their professional stages.

3. MGMP can be a powerful agency to help teachers enhance their quality. As some of the teachers in the study show, collaboration through MGMP activities have helped them improve their English as well as pedagogical practices. It is recommended that teachers' participation in MGMP can be further facilitated, monitored, and perhaps also be integrated into the certification program.

This study has attempted to delve into English teachers' proficiency in their professional development across different regions in Indonesia. As with other assessments, this study may still have issues with limitations, validity and reliability. Nevertheless, the researchers wish to reiterate that English teachers' adequate proficiency is not a given capital at the time of teacher service and thus it takes a serious collaboration between English teacher colleges, the Ministry, and the school communities to challenge teachers to enhance their competence. 


\section{Acknowledge ment}

This study was funded by a 2018 research grant from the Directorate of Research and Community Service, the Indonesian Ministry of Research, Technology, and Higher Education.

Anita Lie (anita@ ukwms.ac.id) is a professor at Widya Mandala Catholic University, Surabaya, Indonesia. Her areas of research are teacher professional development, English education, and heritage language learning. She led the team for this research project and was responsible for the design and data analysis.

Siti Mina Tamah (mina@ ukwms.ac.id) is a full-timer at the English Department of Widya Mandala Catholic University, Surabaya, Indonesia. She has great interest in language teaching methods. Her current research topics are related to Cooperative Learning and Assessment. She designed the assessment instruments in this project.

Trianawaty (trianawaty@ukwms.ac.id) is a faculty member of Faculty of Teacher Training and Education, Widya Mandala Catholic University, Surabaya, East Java province. In 2014, she gained her master degree in Applied Linguistics from Universitas Katolik Atma Jaya Jakarta. She helped in data collection in this project.

Katarina Retno (retno@ ukmc.ac.id) teaches Bahasa Indonesia at Musi Charitas Catholic University. Placed at Primary School Teacher Education Study Program, she teaches some courses, among others, Low Level Indonesian Learning, High Level Indonesian Language Learning, Educational Research Methods, and Classroom Action Research. She was responsible for data collection in Palembang and Yogyakarta.

Fransiskus Jemadi (ikinjemadi@ gmail.com) is an English lecturer at Universitas Katolik St. Paulus Ruteng-Flores-Indonesia. He is passionate about teaching English as a foreign language and has great interest in conducting research on teaching English and as sessment. $\mathrm{He}$ helped in data collection among teachers in Ruteng in this project.

Aniroh, K. (2009). From English as a general school subject onto English as a medium for learning specific subjects: The need to shift in the teaching orientation. TEFLIN Journal 20(2): 169-179.

Anugerahwati, M. \&Saukah, A. (2010). Professional competence of English teachers in Indonesia: A profile of exemplary teachers. Indonesian Journal of English Language Teaching 6(2): 47-59.

Borko, H. (2004). Professional development and teacher learning: Mapping the terrain. Educational Researcher 33(8): 3-15. http://dx.doi.org/10.3102/0013189x033008 $\underline{003}$

Coleman, H. (2009). Indonesia's 'International Standard Schools': What are they for? Paper presented at the 8th Language and Development Conference, Dhaka, 23-25 June 2009.

Grossman, P. (1992). Why models matter: An alternate view on professional growth in teaching. Review of Educational Research 62(2):171.http://dx.doi.org/10.2307/117057 $\underline{9}$

Hakim, A. (2016). Analisis gambaran kompetensi guru terhadap prestasi belajarsiswa SMP pada ujian nasional tahun 2015 Provinsi Daerah Istimewa Yogyakarta. (Analysis of teachers' competence and junior secondary school students' achievements in national exam in 2015 in Yogyakarta). Retrieved 9 August 2018 from http://publikasi.data.kemdikbud.go.id/ uploadDir/isi_7B7AEBCB-7719-4CF0B332-123509F7E899_.pdf

Hargreaves, A. (2000). Four ages of professionalism and professional learning. Teachers and Teaching: History and Practice 6(2): 151-182.

Hargreaves A, Fullan M (2012) Professional Capital: Transforming Teaching in Every School. New York: Teachers College Press.

Harjanto, I., Lie, A. Wihardini, D., Pryor, L., \& Wilson, M. (2018). Community-based teacher professional development in remote 
areas in Indonesia. Journal of Education

for Teaching 44(2): 212-231. https://doi. org/10.1080/02607476.2017.141 5515

Jackson, R. (2009). Never work harder than your students and other principles of great teaching. Alexandria, VA: ASCD.

Lengkanawati, N. (2005). EFL Teachers' competence in the context of English curriculum 2004: Implications for EFL teacher education. TEFLIN Journal 26(1): 79-92.

Lie, A. (2007). Education policy and EFL curriculum in Indonesia: Between the commitment to competence and the quest for higher test scores. TEFLIN Journal 18(1): 1-14.

Mehrpour, S. \&Moghadam, M. (2018). Exploring the effect of self-reflection through awareness raising on novice and experienced Iranian EFL teachers' pedagogical beliefs enactment. The Journal of Asia TEFL 15(3): 630-648.

Miles, M.B., Huberman, A.M., \&Saldana, J. (2014). Qualitative Data Analysis, A Methods Sourcebook, $3^{\text {rd }}$ edition. USA: Sage Publications.

Nair, R. \& Arshad, R. (2018). The discursive construction of teachers and implications for continuing professional development. Indonesian Journal of Applied Linguistics 8(1): 131-138. doi: 0.17509/ijal.v8i1.11472

NCSSFL-ACTFL Can-Do Statements. (2012). Retrieved 10 June 2018 from https://www.actfl.org/publications/guide lin es-and-manuals/ncssfl-actfl-can-dostatements

Othman, J. \& Nordin, A. (2013) MUET as a predictor of academic achievement in ESL teacher education. GEMA Online ${ }^{\circledR}$ Journal of Language Studies 13(1): 99-111.

Prasetyo, S. (2017). UjiKompetensi Guru, tes sesuaikankompetensi guru. Jawa Pos. 2 July. Retrieved 9 August 2018 from https://www.jawapos.com/pendidikan/02/0 7/2017/uji-kompetensi-guru-tes-sesuaikankompetensi-guru
Putra, I. (2017). Pretest UKG (UjianKompetensi Guru) ini ujianapaya? Kompasiana. Retrieved 9 August 2018 from https://www.kompasiana.com/indrayahdi/59afb95aa32cdd1bae7721d3/ pretestukg-ujian-kompetensi-guru-ini-ujian-apayaaa

Renandya, W., Hamid, F. \& Nurkamto, J. (2018). English language proficiency in Indonesia: Issues and Prospects. The Journal of Asia TEFL 15(3): 618-629.

Richards, J. C. (2017). Teaching English through English: Proficiency, Pedagogy and Performance. RELC Journal 48(1): 730.

Schle icher, A. (2015). Schools for $21^{\text {st }}$-Century Learners: Strong Leaders, Confident Teachers, Innovative Approaches, International Summit on Teaching Profession. OECDPublishing. http://dx.doi.org/10.1787/ 9789264231191-en

Sharif, A. (2013). Limited proficiency English teachers' language use in science classrooms. GEMA Online ${ }^{\circledR}$ Journal of Language Studies 13(2): 65-80.

Soepriyatna. (2012). Investigating and assessing competence of high school teachers of English in Indonesia. Malaysian Journal of ELT Research 8(2): 38-49.

Tamah, S. M. \& Lie, A. (2019). Analysis of a Research Instrument to Map English Teachers' Proficiency. IJEE (Indonesian Journal of English Education), 6(1), 48-64. doi:10.15408/ijee.v6i1.11888

http $/ /$ journal.uinjkt.ac.id/index.php/ijee/arti cle/view/11888/pdf

Tsang, A. (2017). EFL/ESL teachers' general language proficiency and learners' engagement. RELC Journal48(1): 99-113.

Tsang, W.L. (2011). English meta language awareness among primary school teachers in Hong Kong. GEMA Online ${ }^{\circledR}$ Journal of Language Studies 11(1): 1-16.

Yumarnamto, M. (2017). The career path of an Indonesian EFL teacher: a professional capital perspective. RELC Journal https ://doi. org/10. 1177/0033688217730141 